\title{
Factorial Validation of a Writing Self-regulation Scale: With and without Acceptably Cross Loading Items
}

\author{
Ebrahim Khodadady \\ Ferdowsi University of Mashhad, Iran \\ Email: ekhodadady@ferdowsi.um.ac.ir \\ Salim Yassami \\ Ferdowsi University of Mashhad, Iran
}

\begin{abstract}
This study explored the factorial validity of a writing self-regulation scale (WSRS) by administering it to $\mathbf{1 2 5}$ learners of English language preparing to sit for the writing module of the IELTS examination in Tehran, Iran. The submission of the written responses elicited on the WSRS to the Principal Axis Factoring and Varimax rotation of the data resulted in extracting five factors, i.e., i.e., Instructions, Editing, Semantic Revision, Accessing Samples, and Syntactic Revision explaining 53\% of total variance in the scale. The reliability and correlational analyses showed that not only the WSRS but also its extracted factors were highly reliable and strongly related to each other. The inclusion of positive and acceptably cross loading items (ACLIs) in both the WSRS and factors, however, increased their reliability and inter correlations even higher suggesting that the ACLIs should be reported in factorial studies and included in exploring the inter relationships among the factors. It is suggested that the ACLIs be employed in investigating the relationship of the WSRS with external measures of ability such as scores obtained on language proficiency tests.
\end{abstract}

Index Terms - factorial validity, self-regulation, writing ability, cross loading items, language proficiency

\section{INTRODUCTION}

Self regulation is defined by Kanfer (1970) as controlling one's manner and behavior without considering external reinforcement or punishment contingencies. According to Baumeister and Vohs (2007), however, self-regulation boosts the adaptability and flexibility of human behavior so to adapt their deeds to a broad range of social and situational requirements. In other words it deals with the human capacity to take these requirements as their priority and change their responses accordingly (Polivy, 1998).

Leventhal and Cameron (1987) identified self-regulated persons as active problem solvers who employ their available abilities in order to increase their performance in whatever goals they set for themselves. Those who selfregulate themselves fulfill their tasks completely and successfully because they do their outmost to fill the gap between their present status and goals. Self- regulated learning for these people is therefore an active constructive process whereby they "set goals for their learning and monitor, regulate, and control their cognition, motivation, and behavior, guided and constrained by their goals and the contextual features of the environment" (Pintrich \& Zusho, 2002, p. 64).

Since it deals with learning, self regulation has gained an interdisciplinary status and been employed in fields as diverse as sports, psychology and teaching English as a foreign language and referred to as self-control, selfmanagement, self-reinforcement, and self-instruction. Depending on the type of learners' needs, various types of questionnaires have been developed to measure self regulation. As an example, in sports, self-regulation skills are employed to measure performance differences when athletes encounter possibilities normally referred to as life demands and threats. They are based on the premise that self-regulation is fundamental for free will and socially desirable behavior and contributes to many sought-after outcomes, among which task performance, school and work success, social popularity, mental health and adjustment, and good interpersonal relationships are of great importance (Baumeister, Heatherton, \& Tice, 1994; Duckworth \& Seligman, 2005).

Baumeister and Vohs (2007) explored several criteria involved in self-regulation i.e., motivation; standards, monitoring, and self-regulatory monitoring. They believe that motivation is not lauded in self-regulation theories though it is an indispensable part of not only human but also animal self-regulation. They are, nonetheless, closely related because self-regulatory power is needed as a filter to control and moderate motivation and stop undesirable impulses in various situations. Self-regulation is mostly self-stopping in the sense that a dieter eschews eating, a convalescing addict stops using drugs, and a drunk refrains drinking. Much of self-regulation is, therefore, used for constraining one's motivation in order to serve the goal of being accepted by others and pursuing progressive selfinterest over naïve and myopic self-interest. Motivation is deep-seated in life, but it also needs to be controlled by selfregulatory power to obtain the best result. 
Kim, Deci and Zuckerman (2002) developed a Self-Regulation of Withholding Negative Emotions (SRWNE) questionnaire and examined its reliability and validity in three different studies. In the first study, they found that the SRWNE was distinct from emotional regulation measures and could thus be appropriate to measure styles of selfregulation and to elucidate the negative affect-health relation. In the second study, test-retest reliability of scores on the SRWNE subscales was examined as was the empirical validity of the SRWNE on coping strategies and health. The results showed that the SRWNE was significantly related to the self-report of health and might be employed to foretell how people cope with stress. The last study compared two contexts: Korean and American and suggested construct comparability of the SRWNE across cultures and genders. The elements comprising the SRWNE questionnaire were optimism, social anxiety, awareness, and mistrust of others, external focus, psychosomatics, problem-focused, supportseeking, denial, rumination and acceptance.

By employing the 56-item self-regulation questionnaire designed to test Kuhl and Fuhrmann's (1998) model, Barkhoff, Heiby and Pagano (2007) studied the level of self-regulation skills between two groups of roller skaters, i.e., elites or professionals and training champions, to determine the extent to which the use of self-regulation skills preceding a competition accounts for differences in the performance of professional and amateur skaters. Both skaters took the questionnaire at two different intervals, one before five competitions and the other before nine competitions. They found that the professional skaters had a low level of volitional inhibition- self-control, higher level of selfdiscipline and life demands, and also a tremendously higher level of threats compared to the amateur skaters. Also both skaters generally had a higher level of self-regulation competency and self-discipline in their earlier competitions than their later events.

McCullough and Willoughby (2009) believed that many of the connections of religiousness and health, well-being and social behavior might be because of religions' impacts on self-control and self regulation. By using Carver and Scheier's (1998) theory of self-regulation as a framework to organize their empirical research, McCullough and Willoughby introduced six propositions: (a) that religion can promote self-control, (b) that religion impacts how goals are chosen, pursued, and organized, (c) that religion helps boost self-monitoring, (d) that religion nourishes the development of self-regulatory strength, (e) that religion prescribes and fosters proficiency in a suite of self-regulatory behaviors, and (f) that some religions' influences on health, well-being, and social behaviors may stem from their impact on self-control and self-regulation. The evidence obtained by the researchers generally confirmed all the propositions.

Wilde (2010) carried out a research on self-regulation and the response to concerns about food and beverage marketing to children in the United States. The results showed that while self-regulated children had a healthier consumption of food and beverages, pinpointing the fact that media and advertisement had not had much influence on them, less self-regulated children were more at risk of unhealthy food and beverages if they were left with their parents' supervision. The researchers, therefore, concluded that it is the responsibility of government to take care of this issue and develop self-regulated citizens.

Magno (2009) hypothesized that when students are asked to write a composition in any given second language, they use specific approaches to learning and experience self-regulatory processes. To test the hypothesis, Magno administered the Academic Self-Regulated Learning Scale (A-SRL-S) and the Revised-Learning Process Questionnaire (R-LPQ-2F) to 294 college students majoring in English, communication arts, literature, mass communications, and journalism from different universities in the Philippines. The former addressed concepts like memory strategy, goal setting, self-evaluation, seeking assistance, environmental structuring, responsibility and organizing whereas the latter tapped into concepts like intrinsic motivation, commitment to work, relating ideas, understanding, fear of failure, aim for qualification, minimizing scope of study, and memorization. The results showed that only deep approach, i.e., actively and mentally engaging one's self with a given task (Kember, Biggs, \& Leung, 2004), correlated significantly with the factors of self-regulation except for environmental structuring and demanding help. Although deep approach and surface approach, i.e., memorization of the material that doesn't require understanding (Entwistle, McCune, $\&$ Walker, 2001), correlated highly with each other, only the deep approach increased the variance in all self-regulation components. The latter, however, only boosted the variance in memory strategy.

Matuga (2009) explored self-regulation, goal orientation and academic achievement of 40 secondary students studying online university courses in the sciences by administering the Motivation Strategies for Learning Questionnaire. Each course was taught by two instructors, i.e., a university professor and school teacher, in six weeks. The results showed that teaching the courses by two professors was a success. They also indicated that goal orientation is affected by taking online university courses. The learners engaged in those courses with a performance goal orientation were worried to get good grades and therefore took part in activities that would help them achieve the grades. Furthermore, a positive and significant interaction effect was found between learners' achievement level and pre- and post- measures of motivation. Self-regulation subscales indicated a deeper and more sophisticated view of learners' skills and abilities to plan, monitor, and evaluate their own learning of the university curriculum.

Porath, Ngara, Lai, Fogel and Lupart (2010) explored the relationship between self-regulation and children's understanding of teaching. They identified the genius students aged between six and seventeen and asked them how they would like to be taught core academic subjects. By using grounded theory, i.e., open coding, constant comparison, and theoretical integration of data to interpret results (Henwood \& Pidgeon, 2003), and neo-Piagetian cognitive 
development theory, the data were analyzed and five levels of understanding were articulated that shaped a developmental trajectory in which young children saw teaching as an action-based and concrete process focused on helping them do things right. The data showed that by middle childhood, understanding of fundamental principles of teaching and learning were evident, then consciousness of the interdependence of teaching and learning. In early adolescence, emergent philosophical ideas and views on the very nature of knowledge were expressed through using self-regulatory power. Some adolescents also took advantage of self-regulation strategies and demonstrated personal philosophies of learning by focusing on growth, mutual partnership, and excitement of learning.

Rothschild and Klingenberg (1990) criticized the assessment and evaluation of writing in the ESL classroom as the teacher's prerogative and tried to bring them into the classroom by having the learners evaluate themselves and their own writing within the class ambiance. The students were trained to adopt an evaluation scale and use it to evaluate not only their own writing but also their peers'. The researchers then tested the effects of self-and-peer assessment and evaluation on the participants' performance on writing task at the end of the term. The results showed that the students assessed the writings totally differently from their teachers, i.e., they employed a self-regulation scale. Since they were involved not only in the writing process itself but also in its assessment, the learners developed a positive attitude towards writing.

Arsal (2010) explored the effects of 60 preservice science teachers' diaries on self-regulation strategies. After assigning the teachers into control and experimental groups, Arsal employed Pintrich's self-regulation model consisting of three strategies, i.e., cognitive, metacognitive or self-regulatory, and resource managing. It was found that only the experimental group had utilized the self-regulatory strategies and completed the diary-report form for fourteen weeks. Compared to the control group, they had gained much higher academic achievement.

Hamman (2005) administered three measures of academic writing beliefs, self-regulatory behaviors, and epistemological beliefs to pre-service teachers to explore their relationship with academic writing tasks. While both self-regulation and knowledge of cognition were found to be positively related to writing excitement and enjoyment, knowledge of cognition showed negative relations with beliefs of ability as a fixed entity. Self-assessment and selfregulation were, however, directly related to the enjoyment of the writing process and its learnability. Hamman concluded that the teachers who were more self-regulated believed they could learn to improve their writing. Their beliefs and emotions about leaning and writing, therefore, played a pivotal and complex role in their self-regulation behaviors.

While the studies cited above deal with self-regulation in general, the present study is developed on the premise that a single self-regulatory scale such as the checklist designed by Hashemi, Khodadadi, and Yazdanmehr (2009) [referred to as HKY09 henceforth] can be utilized to help English language learners achieve the goal of writing for proficiency tests such as the IELTS for which they sit in preparations courses in Iran. Since the checklist contains items which direct the learners towards the attainment of a given Goal, i.e., performing well on writing examinations, as all selfregulatory scales do (e.g., Zimmerman, 2000), this study aims to find out whether it is a valid Writing Self-Regulation Scale and whether the factors extracted in this study meet the criterion of reliability and show significant relationships with each other.

\section{METHODOLOGY}

\section{A. Participants}

Seventy one male $(56.8 \%)$ and 54 female $(43.2 \%)$ learners of IELTS took part voluntarily in the presents study. Their age ranged between 22 and $52($ mean $=31.31, \mathrm{SD}=6.41)$. Eleven $(8.8 \%), 24(19.2 \%), 18(14.4 \%), 23(18.4 \%), 14$ (11.2), 14 (11.2) and 21 (16.8\%) were studying at Arianpour, Kish, Mojtame Fani Tehran, Safir, Shoukuh, Tehran Oxford and Vazir institutes, respectively in Tehran, the capital of Iran. These seven institutes were among the most famous IELTS centers where one of the researchers taught the IELTS and could thus encourage both the teachers and learners to participate in the study. Eighty one $(64.8 \%), 42(33.6 \%)$ and $2(1.6 \%)$ of learners were holding BA/BSc, MA, MSc., and PhD degrees, respectively. With the exception of only one learner who had studied English just for one year, $45(36 \%), 38(30.4 \%), 27(21.6 \%)$, and 14 (11.2) had been studying it for two, three, four and five years or more, respectively. Sixty four $(51.2 \%)$ were studying IELTS in order to pursue their higher education in English speaking countries and $60(48 \%)$ needed it for immigration purposes. Only one was learning the IELTS as part of professional development for his job.

\section{B. Instrument}

The instrument used in this study consisted of two parts. The first part required the participants to provide the researchers with the information related to their age, gender, the educational degree obtained, and the years and purpose of studying the English language. The second part contained the 20-item checklist designed by HKY09 and employed as a Writing Self-Regulation Scale (WSRS) in this project. The items require the participants to choose from among four alternatives developed on a Likert scale, i.e., not at all (0), a little (2), adequately (4), and to a great extent (6). The items were divided by HKY09 into two parts, i.e., task prompt and task procedures, consisting of nine logical factors, i.e., goal, authenticity, topic, instruction, pre-writing, draft-writing, revising, editing, and publishing. (The WSRS as well as its descriptive statistics are given in Appendix.) 


\section{Procedure}

After having the biodata part and WSRS printed, the researchers took and gave them to almost all the instructors of writing module of the IELTS in Arianpour, Kish, Mojtame Fani Tehran, Safir, Shoukuh, Tehran Oxford and Vazir institutes in person. Upon explaining the purpose of the research and its relevance to what they taught, thirty instructors volunteered to administer them in the last session of the course provided they were supplied with the results of the study. Adequate number of copies were then made of the scale and taken to these instructors one session before the last and one of the researchers attended the session if the relevant instructor wished so. The researchers collected the responses the day after the administration if the teachers themselves administered the WSRS.

\section{Data Analysis}

The descriptive as well as inferential statistical analyses were carried out by utilizing the SPSS version 19.0. The reliability of the WSRS was estimated via Cronbach Alpha. The Principal Axis Factoring method was employed to extract rotated factors. Similar to Khodadady (2009), Kaiser criterion, i.e., eigenvalues higher than 1, was used to determine the number of factors extracted in this study. Following Khodadady and Hashemi (2010), the unrotated factor matrix was skipped and all correlation coefficients with their frequency and magnitudes were estimated and reported. By employing Khodadady's (2010) findings and suggestions the WSRS was factorially analysed two times, i.e., first with the factors having positive and acceptably cross loading items (ACLIs), i.e., 0.30 and higher, and then with the factors without ACLIs to test the following three hypotheses:

H1. The twenty items comprising the WSRS will show strong interrelationships with each other.

H2. The twenty items comprising the WSRS will load on nine logical factors.

H3. The WSRS and the extracted factors with ACLIs will show higher inter correlations with each other than the factors without ACLIs.

\section{RESULTS AND DISCUSSION}

In order to determine whether running a factor analysis will be acceptable or not, the data were submitted to KaiserMeyer-Olkin Measure of Sampling Adequacy and the value .83 was obtained. According to Kaiser (1974), KMOs in the .80s are "meritorious," (cited in DiLalla \& Dollinger, 2006, p. 250) and the factors extracted can thus be comfortably accepted as underlying variables of WSRS. Furthermore, the significant Bartlett's Test of Sphericity, i.e., $\mathrm{X}^{2}=1.260, \mathrm{df}=190, \mathrm{p}<.001$, indicated that the correlation matrix was not an identity matrix.

Table 1 presents the ordered initial and extracted communalities obtained via Principal Axis Factoring from the twenty items comprising the WSRS. As can be seen, the initial communalities range between 0.68 and 0.43 . These results are compatible with those obtained by Khodadady (2010) whose initial communalities also ranged between .68 and .33. He challenged MacCallum, Widaman, Zhang and Hong (1999) who believed that selecting small samples would be all right if item communalities were consistently high, i.e., .80 or above. Since his sample was as large as possible, i.e., 1469, and educationally homogenous, i.e., only high school students, he concluded that his obtained range must be normal as is the case in this study, too.

TABLE 1

ORDERED COMMUNALITIES EXTRACTED VIA PRINCIPAL AXIS FACTORING

\begin{tabular}{|l|l|l|l|l|l|l|l|l|}
\hline Item & Initial & Extraction & Item & Initial & Extraction & Item & Initial & Extraction \\
\hline 12 & 0.68 & 0.68 & 16 & 0.62 & 0.62 & 1 & 0.52 & 0.51 \\
\hline 3 & 0.66 & 0.49 & 18 & 0.62 & 0.51 & 7 & 0.52 & 0.41 \\
\hline 6 & 0.66 & 0.86 & 14 & 0.60 & 0.53 & 10 & 0.48 & 0.43 \\
\hline 8 & 0.64 & 0.71 & 13 & 0.59 & 0.52 & 11 & 0.46 & 0.34 \\
\hline 19 & 0.64 & 0.58 & 2 & 0.56 & 0.42 & 5 & 0.44 & 0.40 \\
\hline 20 & 0.62 & 0.50 & 9 & 0.54 & 0.53 & 4 & 0.43 & 0.37 \\
\hline 15 & 0.62 & 0.64 & 17 & 0.54 & 0.52 & & & \\
\hline
\end{tabular}

Along with those of Khodadady (2010), the communalities presented in Table 1 support Costello and Osborne's (2005) suggestion for the approximate range of .40 to .70 in social sciences. Not only do the communalities of .80 rarely appear in applied linguistics but also the inter correlations among the items comprising scales such as the WSRS seldom reach that magnitude as shown in Table 2. As can be seen, the highest correlation coefficient obtained among the items comprising the WSRS is 0.58 . Although its size is noticeably lower than the highest correlation found by Khodadady (2010), i.e., 0.69, both are smaller than 0.80. However, out of 190 coefficients, $58.4 \%$ correlate significantly at 0.37 (p <.01) and higher with each other, indicating that the majority of items comprising the WSRS are well interrelated. These results support the first hypothesis that the twenty items comprising the WSRS will correlate highly among themselves. 
TABLE 2

THE FREQUENCY (F), PERCENT (P) AND CUMULATIVE PERCENT (CP) OF 1080 CORRELATION COEFFICIENTS (CC) OBTAINED AMONG THE 20 ITEM COMPRISING THE WSRS

\begin{tabular}{|c|c|c|c|c|c|c|c|c|c|c|c|}
\hline $\mathrm{CC}$ & $\mathbf{F}$ & $\mathbf{P}$ & CP & $\mathrm{CC}$ & $\mathbf{F}$ & $\mathbf{P}$ & CP & $\mathrm{CC}$ & $\mathbf{F}$ & $\mathbf{P}$ & $\mathrm{CP}$ \\
\hline 0.58 & 1 & 0.5 & 0.5 & 0.43 & 8 & 4.2 & 34.7 & 0.28 & 1 & 0.5 & 82.1 \\
\hline 0.57 & 1 & 0.5 & 1.1 & 0.42 & 7 & 3.7 & 38.4 & 0.27 & 3 & 1.6 & 83.7 \\
\hline 0.56 & 1 & 0.5 & 1.6 & 0.41 & 2 & 1.1 & 39.5 & 0.26 & 6 & 3.2 & 86.8 \\
\hline 0.55 & 2 & 1.1 & 2.6 & 0.40 & 6 & 3.2 & 42.6 & 0.25 & 7 & 3.7 & 90.5 \\
\hline 0.54 & 3 & 1.6 & 4.2 & 0.39 & 9 & 4.7 & 47.4 & 0.24 & 2 & 1.1 & 91.6 \\
\hline 0.53 & 7 & 3.7 & 7.9 & 0.38 & 8 & 4.2 & 51.6 & 0.23 & 3 & 1.6 & 93.2 \\
\hline 0.52 & 4 & 2.1 & 10 & 0.37 & 13 & 6.8 & 58.4 & 0.22 & 3 & 1.6 & 94.7 \\
\hline 0.51 & 4 & 2.1 & 12.1 & 0.36 & 5 & 2.6 & 61.1 & 0.20 & 2 & 1.1 & 95.8 \\
\hline 0.50 & 2 & 1.1 & 13.2 & 0.35 & 10 & 5.3 & 66.3 & 0.18 & 3 & 1.6 & 97.4 \\
\hline 0.49 & 9 & 4.7 & 17.9 & 0.34 & 7 & 3.7 & 70 & 0.17 & 1 & 0.5 & 97.9 \\
\hline 0.48 & 2 & 1.1 & 18.9 & 0.33 & 5 & 2.6 & 72.6 & 0.13 & 2 & 1.1 & 98.9 \\
\hline 0.47 & 6 & 3.2 & 22.1 & 0.32 & 4 & 2.1 & 74.7 & 0.11 & 1 & 0.5 & 99.5 \\
\hline 0.46 & 3 & 1.6 & 23.7 & 0.31 & 3 & 1.6 & 76.3 & 0.05 & 1 & 0.5 & 100 \\
\hline 0.45 & 9 & 4.7 & 28.4 & 0.30 & 4 & 2.1 & 78.4 & Total & 190 & 100 & \\
\hline 0.44 & 4 & 2.1 & 30.5 & 0.29 & 6 & 3.2 & 81.6 & & & & \\
\hline
\end{tabular}

The results presented in Table 2 are also compatible with Khodadady's (2010) in a different way. After comparing the correlation coefficients (CCs) obtained among the 47 items forming the CEELT with the 34 items comprising the Beliefs about Language Learning Inventory (BALLI) developed by Horwitz $(1985,1988)$ he found that while the CEELT produced a large number of high CCs, the BALLI failed to do so. The findings of this study, therefore, provide further evidence for Khodadady's observation that the more conceptually related the items comprising a given questionnaire are, the higher the inter correlations among them and thus "the fewer the number of factors extracted" (p. 56) will be.

Table 3 presents the rotated factor matrix obtained via Principal Axis Factoring, Varimax with Kaiser Normalization. As can be seen, all twenty items comprising the WSRS load "acceptably" (Khodadady \& Hashemi 2010, p.18), i.e. .30 or higher, only on five factors. These results disconfirm the second hypothesis that the twenty items comprising the WSRS will load on nine logical factors. For example, item three, i.e., to what extent did the task help you to apply classroom learning to the real world, is dubbed as authenticity by HKY09. This item, however, loads on two factors in this study and thus shows the test takers' tendency to relate authenticity to the instructions given and editing rather than treat it as a single factor.

TABLE 3

ROTATED FACTOR MATRIX OF 20 ITEMS COMPRISING THE WSRS

\begin{tabular}{|c|c|c|c|c|c|c|c|c|c|c|c|}
\hline \multirow{2}{*}{ Item } & \multicolumn{5}{|c|}{ Factors } & \multirow{2}{*}{ Item } & \multicolumn{5}{|c|}{ Factors } \\
\hline & 1 & 2 & 3 & 4 & 5 & & 1 & 2 & 3 & 4 & 5 \\
\hline 1 & $*$ & $*$ & .55 & .39 & $*$ & 11 & .37 & $*$ & $*$ & $*$ & $*$ \\
\hline 2 & .51 & $*$ & $*$ & $*$ & $*$ & 12 & .31 & .35 & .61 & $*$ & $*$ \\
\hline 3 & .33 & .48 & $*$ & $*$ & $*$ & 13 & .43 & .34 & .33 & $*$ & * \\
\hline 4 & $*$ & $*$ & .56 & $*$ & $*$ & 14 & $*$ & $*$ & .33 & $*$ & .52 \\
\hline 5 & $*$ & $*$ & $*$ & $*$ & .44 & 15 & $*$ & .55 & $*$ & .39 & $*$ \\
\hline 6 & .87 & $*$ & $*$ & $*$ & $*$ & 16 & $*$ & $*$ & $*$ & $*$ & .72 \\
\hline 7 & $*$ & .51 & $*$ & $*$ & $*$ & 17 & $*$ & .59 & $*$ & $*$ & $*$ \\
\hline 8 & .32 & $*$ & $*$ & .70 & $*$ & 18 & $*$ & .36 & $*$ & .49 & $*$ \\
\hline 9 & $*$ & .52 & .32 & $*$ & .30 & 19 & .41 & .40 & $*$ & $*$ & .35 \\
\hline 10 & .52 & $*$ & $*$ & $*$ & $*$ & 20 & $*$ & .41 & $*$ & .44 & $*$ \\
\hline
\end{tabular}

The results presented in Table 3 are in line with Khodadady's (2010) findings in that no factor could be found in the matrix upon which the items forming other factors did not cross load acceptably. Similar to what he found, 14 items $(70 \%)$ cross loaded on at least one other factor in the present study and thus questioned the factorial validity of studies in which similar patterns were not found.

Table 4 presents the eigenvalues as well as the variance explained by the five rotated factors extracted in this study. (The table presenting the total variance explained by all factors is not given to save space.) As can be seen, each of the five factors enjoys an eigenvalue higher than one and together they explain almost 53\% of variance in the WSRS and thus provide further support for the necessity of establishing the factorial validity of the WSRS. None of the 20 items forming the nine logical factors established by HKY09, however, load exclusively on any of the nine and thus question their conceptualization factorially. 
TABLE 4

EIGENVALUES OF ROTATED FACTORS THE VARIANCE EXPLAINED BY EACH AND ALL

\begin{tabular}{|l|l|l|l|l|}
\hline $\begin{array}{l}\text { Factors } \\
\text { Extracted }\end{array}$ & Logical factors (HKY09) & Items & $\begin{array}{l}\text { Eigen- } \\
\text { value }\end{array}$ & $\begin{array}{l}\text { Variance explained } \\
(\mathbf{5 2 . 7 3 \%})\end{array}$ \\
\hline Instructions & $\begin{array}{l}\text { Authenticity, Draft-writing, Goal, } \\
\text { Instructions, Pre-writing, Publishing, } \\
\text { Revising }\end{array}$ & $\begin{array}{l}2,3,6,8,10,11, \\
12,13,19\end{array}$ & 2.558 & 12.789 \\
\hline Editing & $\begin{array}{l}\text { Authenticity, Editing, Instructions, Pre- } \\
\text { writing, Publishing, Revising }\end{array}$ & $\begin{array}{l}3,7,9,12,13,15, \\
17,18,19,20\end{array}$ & 2.487 & 12.436 \\
\hline $\begin{array}{l}\text { Semantic } \\
\text { Revision }\end{array}$ & Editing, Goal, Pre-writing, Revising, Topic & $1,4,9,12,13,14$ & 1.885 & 9.427 \\
\hline $\begin{array}{l}\text { Accessing } \\
\text { Samples }\end{array}$ & Editing, Goal, Instructions, Publishing & $1,8,15,18,20$ & 1.813 & 9.064 \\
\hline $\begin{array}{l}\text { Syntactic } \\
\text { Revision }\end{array}$ & Editing, Pre-writing, Publishing, Topic & $5,9,14,16,19$ & 1.804 & 9.018 \\
\hline
\end{tabular}

One of the greatest advantages of establishing the factorial validity of a given scale such as the WSRS is dispensing with certain vague and personal views and finding a common thread among the items which constitute a certain factor. As can be seen in Table 3 and 4, for example, even when ACLs are removed from the factor analysis, the three logical factors of HKY09, i.e., Goal, Revising, and Topic load on a single factor called Semantic Revision in this study. Item 12 , i.e., did you revise your jotted down ideas to make sure of their sensibility and accurateness to the reader, has the highest loading on this factor (0.61) and thus helps the researchers understand that the goal in item 1, Was the overall goal of the task clear and void of ambiguity to you as a learner, with a loading of 0.55 , is in fact understood by the test takers in terms of ideas expressed in item four dubbed as the topic, Was the topic of the task stimulating and appropriate to your age and educational level (loading $=0.56$ )?

Ideas, goals and topic of a given writing task are expressed in the semantic words forming the task i.e., adjectives, adverbs, nouns and verbs. Khodadady (2000), for example, developed a vocabulary test on the semantic words comprising the passages of the reading comprehension section of TOEFL and administered it along with the reading comprehension test to both native and non-native speakers of English. His results showed that the knowledge of these contextual semantic words is the best predictor of both speakers' reading comprehension ability. Future research must, therefore, show whether the third factor extracted from the WSRS in this study, i.e., Semantic Revision, shows stronger relationship with the reading comprehension ability of test takers than the other factors.

Table 5 presents the descriptive statistics of the WSRS and its five factors along with their inter correlations. As can be seen, the five factors with positive ACLIs are all more reliable than those without ACLIs. This is particularly true for the factors upon which fewer items load. The reliability of Syntactic Revision, for example, drops from 0.79 to 0.68 simply because the number of items upon which they load acceptably drops from five to three. The very acceptance of ACLIs, however, increases not only the constituting number of the WSRS from 20 to 35 but also the reliability of the SWRS as a whole, i.e., 0.96 compared to 0.92 .

TABLE 5

DESCRIPTIVE STATISTICS OF WSRS, ITS FACTORS WITH AND INTER CORRELATIONS OF THE WSRS AND ITS FACTORS WITH ACCEPTABLY CROSS LOADING ITEMS (ACLIS) AND WITHOUT ACLIS

\begin{tabular}{|c|c|c|c|c|c|c|c|c|c|}
\hline \multirow{2}{*}{ Factors Extracted } & \multirow{2}{*}{$\begin{array}{l}\# \text { of } \\
\text { Items }\end{array}$} & \multirow{2}{*}{ Mean } & \multirow{2}{*}{$\begin{array}{l}\text { Std. } \\
\text { Deviation }\end{array}$} & \multirow{2}{*}{ Alpha } & \multirow{2}{*}{ WSRS } & \multicolumn{4}{|c|}{ Factors with ACLIs } \\
\hline & & & & & & 1 & 2 & 3 & 4 \\
\hline WSRS & 35 & 152.26 & 46.348 & .96 & 1 & & & & \\
\hline 1 Instructions & 9 & 38.42 & 13.024 & .88 & $.94^{*}$ & & & & \\
\hline 2 Editing & 10 & 43.23 & 14.221 & .89 & $.97^{*}$ & $.88^{*}$ & & & \\
\hline 3 Semantic Revision & 6 & 26.82 & 8.390 & .81 & $.92^{*}$ & $.81^{*}$ & $.86^{*}$ & & \\
\hline 4 Accessing Samples & 5 & 22.22 & 7.393 & .81 & $.88^{*}$ & $.79^{*}$ & $.86^{*}$ & $.75^{*}$ & \\
\hline 5 Syntactic Revision & 5 & 21.57 & 7.115 & .79 & $.86^{*}$ & $.76^{*}$ & $.80^{*}$ & $.81^{*}$ & $.64^{*}$ \\
\hline \multirow{2}{*}{ Factors Extracted } & \multirow{2}{*}{$\begin{array}{l}\# \text { of } \\
\text { Items }\end{array}$} & \multirow{2}{*}{ Mean } & \multirow{2}{*}{$\begin{array}{l}\text { Std. } \\
\text { Deviation }\end{array}$} & \multirow{2}{*}{ Alpha } & \multirow{2}{*}{ WSRS } & \multicolumn{4}{|c|}{ Factors without ACLIs } \\
\hline & & & & & & 1 & 2 & 3 & 4 \\
\hline WSRS & 20 & 87.62 & 25.290 & .92 & 1 & & & & \\
\hline 1 Instructions & 6 & 25.34 & 8.994 & .84 & $.90^{*}$ & & & & \\
\hline 2 Editing & 5 & 22.35 & 7.269 & .79 & $.87^{*}$ & $.70^{*}$ & & & \\
\hline 3 Semantic Revision & 3 & 13.70 & 4.444 & .70 & $.76^{*}$ & $.60^{*}$ & $.61^{*}$ & & \\
\hline 4 Accessing Samples & 3 & 12.98 & 4.923 & .75 & $.83^{*}$ & $.67^{*}$ & $.66^{*}$ & $.57^{*}$ & \\
\hline 5 Syntactic Revision & 3 & 13.25 & 4.563 & .68 & $.75^{*}$ & $.59^{*}$ & $.54^{*}$ & $.48^{*}$ & $.60^{*}$ \\
\hline
\end{tabular}

* Correlation is significant at the 0.01 level (2-tailed).

As it can also be seen in Table 5, the rotated factors extracted from the WSRS show very strong correlations not only with the WSRS itself but also among each other. Syntactic Revision, for example, shows correlations of 0.89 and 0.81 $(p<.01)$ with the WSRS and the Semantic Revision, respectively, indicating that this factor alone explains $79 \%$ and $66 \%$ of variance in the scale and factor three, respectively. However, the coefficients and variances explained drop to 0.75 and 0.48 ( $\mathrm{p}<.01), 56 \%$ and $23 \%$, respectively when their ACLIs are removed. These results thus confirm the third 
hypothesis that the WSRS and the extracted factors with ACLIs will show will show higher inter correlations with each other than the factors without cross loading items.

\section{CONCLUSION}

The checklist designed by Hashemi, Khodadadi and Yazdanmehr (2010) was treated as a Writing Self Regulation Scale (WSRS) in this study because similar to all types of self-regulation questionnaires its twenty items involve actions and thoughts planned for the attainment of a specific goal, i.e., obtaining an acceptable score on an English language proficiency test such as the IELTS (e.g., Zimmerman, 2000). The application of Principal Axis Factoring method to the responses of 125 learners studying the writing module of the IELTS in Iran and Varimax rotation of data resulted in the extraction of five factors in this study, i.e., Instructions, Editing, Semantic Revision, Accessing Samples, and Syntactic Revision.

The WSRS and its factors were subjected to both reliability and correlational analyses with and without positive and acceptably cross loading items (ACLIs). The results showed that the inclusion of the ACLIs increases not only the reliability but also correlations among the factors and results in having a scale which is longer in length and higher in reliability. These findings thus necessitate the reporting of ACLIs in the validation of all psychological and social measures in the literature. Future research projects must show whether having high correlations among the factors with the ACLIs extends to having high correlations with external measures such as actual scores the learners obtain on the IELTS and its reading and writing modules. In other words, future studies must show whether the empirical or external validity of the WSRS and its five factors will be as strong as their internal as well as factorial validities.

APPENDIX

Writing Self-Regulation Scale and its item descriptive statistics $(\mathrm{N}=125)$

\begin{tabular}{|c|c|c|c|c|c|c|}
\hline Item & Not at all & A little & Adequately & To a great extent & Mean & SD \\
\hline $\begin{array}{l}\text { 1. Was the overall goal of the task clear and void of } \\
\text { ambiguity to you as a learner? }\end{array}$ & 4 & 10 & 28 & 83 & 5.04 & 1.558 \\
\hline $\begin{array}{l}\text { 2. Was the task appropriate to your current English } \\
\text { proficiency level? }\end{array}$ & 7 & 16 & 37 & 65 & 4.56 & 1.789 \\
\hline $\begin{array}{l}\text { 3. To what extent did the task help you to apply } \\
\text { classroom learning to the real world? }\end{array}$ & 9 & 17 & 31 & 68 & 4.53 & 1.903 \\
\hline $\begin{array}{l}\text { 4. Was the topic of the task stimulating and appropriate } \\
\text { to your age and educational level? }\end{array}$ & 9 & 19 & 36 & 61 & 4.38 & 1.896 \\
\hline $\begin{array}{l}5 . \text { To what extent was the topic familiar to you and } \\
\text { related to your background knowledge? }\end{array}$ & 7 & 13 & 37 & 68 & 4.66 & 1.756 \\
\hline $\begin{array}{l}\text { 6. To what extent were the instructions clear and } \\
\text { concise? }\end{array}$ & 12 & 17 & 31 & 65 & 4.38 & 2.011 \\
\hline $\begin{array}{l}\text { 7. Were the target reader and the features of the } \\
\text { expected response (e.g. word/time limits, register) } \\
\text { clarified in the instructions? }\end{array}$ & 10 & 14 & 33 & 68 & 4.54 & 1.907 \\
\hline $\begin{array}{l}\text { 8. Were any sample texts provided for you either by the } \\
\text { teacher or the textbook? }\end{array}$ & 13 & 18 & 33 & 61 & 4.27 & 2.037 \\
\hline $\begin{array}{l}\text { 9. Did you spend time on brainstorming, gathering } \\
\text { information or outlining before starting to write? }\end{array}$ & 7 & 21 & 25 & 72 & 4.59 & 1.884 \\
\hline $\begin{array}{l}\text { 10. Did the teacher familiarize you with techniques } \\
\text { such as listing or clustering the ideas, or ask you to } \\
\text { share your ideas in groups? }\end{array}$ & 16 & 21 & 23 & 65 & 4.19 & 2.191 \\
\hline $\begin{array}{l}\text { 11. Did you go through the second stage of putting } \\
\text { ideas into sentences or paragraphs without concern for } \\
\text { mechanics such as spelling or punctuation? }\end{array}$ & 15 & 15 & 31 & 64 & 4.3 & 2.095 \\
\hline $\begin{array}{l}\text { 12. Did you revise your jotted down ideas to make sure } \\
\text { of their sensibility and accurateness to the reader? }\end{array}$ & 14 & 21 & 24 & 66 & 4.27 & 2.13 \\
\hline $\begin{array}{l}\text { 13. Did you receive feedback on content from the } \\
\text { teacher or perhaps a peer in this stage? }\end{array}$ & 17 & 12 & 39 & 57 & 4.18 & 2.095 \\
\hline $\begin{array}{l}\text { 14. To what extent did you edit your writing for } \\
\text { grammar and structure? }\end{array}$ & 14 & 13 & 35 & 63 & 4.35 & 2.033 \\
\hline $\begin{array}{l}\text { 15. To what extent did you edit your writing for word } \\
\text { spelling? }\end{array}$ & 14 & 23 & 24 & 64 & 4.21 & 2.138 \\
\hline $\begin{array}{l}\text { 16. To what extent did you edit your writing for } \\
\text { punctuation, before submitting it? }\end{array}$ & 13 & 19 & 33 & 60 & 4.24 & 2.042 \\
\hline $\begin{array}{l}\text { 17. Did you receive feedback on form from your } \\
\text { teacher in this stage? }\end{array}$ & 14 & 10 & 33 & 68 & 4.48 & 2.022 \\
\hline $\begin{array}{l}18, \text { Did you read out your texts finally to the class or } \\
\text { your peers? }\end{array}$ & 15 & 23 & 37 & 50 & 3.95 & 2.071 \\
\hline $\begin{array}{l}\text { 19. Was the teacher's feedback on the completed piece } \\
\text { of writing motivating? }\end{array}$ & 11 & 35 & 39 & 40 & 3.73 & 1.94 \\
\hline $\begin{array}{l}\text { 20. To what extent did the task performance occur } \\
\text { outside classroom environment (e.g. in a library or } \\
\text { language lab)? }\end{array}$ & 10 & 12 & 24 & 79 & 4.75 & 1.912 \\
\hline
\end{tabular}




\section{REFERENCES}

[1] Arsal. Z., (2010). The effect of diaries on self-regulation strategies of preservice science teachers. International Journal of Environmental and Science Education. 5 (1), 85-103.

[2] Barkhoff, H. , Heiby, \& E. M., Pagano, I. S., (2007). Self-regulation skills of a competitor type vs. a training champion athlete in artistic roller skating: A season long case study in elite sport competitions. The Online Journal of Sport Psychology, 9 (2), 43-57

[3] Baumeister, R. F., \& Heatherton,T. F., \& Tice, D. M. (1994). Losing Control: How and Why People Fail at Self-Regulation. San Diego, CA: Academic Press.

[4] Baumeister, R. F., \& Vohs, K. D., (2007). Self-regulation, ego depletion, and motivation. Social and Personality Psychology Compass, 10, 1-14

[5] Carver, C. S., \& Scheier, M. F. (1998). On the self-regulation of behavior. New York: Cambridge University Press.

[6] Duckworth, A. L., \& Seligman, M. E. P. (2005). Self-discipline outdoes IQ in predicting academic performance of adolescents. Psychological Science, 16, 939-944.

[7] Entwistle, N. J., McCune, V., \& Walker, P. (2001). Conceptions styles and approaches within higher education: analytical abstractions and everyday experiences. In R. J. Sternberg \& L. F. Zhang (Eds.), Perspectives on Thinking, Learning and Cognitive Styles. London: Lawrence Erlbaum.

[8] Gottfredson, M. R., \& Hirschi, T. (1990). A general theory of crime. Stanford, CA: Stanford University Press.

[9] Hammann, L., (2005). Self-regulation in academic writing tasks. International Journal of Teaching and Learning, 17 (1), $15-26$

[10] Hashemi, M. R., Khodadadi, E., \& Yazdanmehr, E. (2009). Learners' evaluation of EFL writing tasks in Iran's ESOL exam preparation courses. Journal of English Language Teaching and Learning, 52 (212), 77-106

[11] Henwood, K., \& Pidgeon, N. (2003). Grounded theory in psychological research. In P. M. Camic, J. E. Rhodes, \& L. Yardley (Eds.), Qualitative research in psychology: Expanding perspectives in methodology and design (pp. 131-155). Washington, DC: American Psychological Society.

[12] Horwitz, E. K. (1985). Using student beliefs about language learning and teaching in the foreign language methods course, Foreign Language Annals, 18, 333- 340.

[13] Horwitz, E. K. (1988). The beliefs about language learning of beginning university foreign language students, The Modern Language Journal, 72, 283-294.

[14] Kanfer, F. H. (1970). Self-regulation: Research, issues, and speculations. In C. Neuringer \& J. L. Michael (Eds.), Behavior modification in clinical psychology (pp. 178- 220). New York: Appleton-Century-Crofts.

[15] Kember, D., Biggs, J., \& Leung, D. Y. P. (2004). Examining the multidimensionality of approaches to learning through the development of a revised version of the learning process questionnaire. Educational Psychology Journals, 74, 261-279.

[16] Khodadady, E. (2009).The Beliefs about Language Learning Inventory: Factorial Validity, Formal Education and the Academic Achievement of Iranian Students Majoring in English. Iranian Journal of Applied Linguistics (IJAL), 12 (1), 115-165.

[17] Khodadady, E. (2010). Factors Underlying Characteristics of Effective English Language Teachers: Validity and Sample Effect. Iranian Journal of Applied Linguistics (IJAL), 13 (2), 47-73.

[18] Khodadady, E., \& Hashemi, M. R. (2010). Construct Validity of Beliefs about Language Learning: Componential or Factorial. Ferdowsi Review, 1(1), 3-20.

[19] Kim, Y., Deci, E., \& Zuckerman, M., (2002). The development of the self-regulation of withholding negative emotions questionnaire. Educational and Psychological Measurement, 62 (2), 316-336

[20] Kuhl, J., \& Fuhrmann, A. (1998). Decomposing self-regulation and self-control: The volitional components checklist. In J. Heckhausen \& C. Dweck (Eds.), Life span perspectives on motivation and control (pp. 15-49). Mahwah, NJ: Erlbaum.

[21] Leventhal, H., \& Cameron, L. (1987). Behavioral theories and the problem of compliance. Patient Education and Counseling, $10,117-138$

[22] Magno, C., (2009). Self-regulation and approaches to learning in English composition writing. TESOL Journal, 1, 1-16.

[23] Matuga, J. M. (2009). Self-regulation, goal orientation, and academic achievement of secondary students in online university courses. Educational Technology \& Society, 12 (3), 4-11.

[24] McCullough, M. E., \& Willoughby, B., L., B., (2009). Religion, self regulation, and self control: Associations, explanations, and implications. Psychological Bulletin, 135 (1), 69-93.

[25] Nicol, D., J., \& Macfarlane-Dick, S., (2006). Formative assessment and self-regulated learning: A model and seven principles of good feedback practice. Studies in Higher Education, 31(2), 199-218.

[26] Pintrich, P. R., \& Zusho, A. (2002). Student motivation and self-regulated learning in the college classroom. In J. C. Smart \& W.G. Tierney (Eds.) Higher Education: Handbook of Theory and Research, Volume XVII. New York: Agathon Press.

[27] Polivy, J. (1998). The effects of behavioral inhibition: Integrating internal cues, cognitive behavior, and affect. Psychological Inquiry, 9, 181-203.

[28] Porath, M., Ngara, C., Lai, Y., Fogel, K., \& Lupart, J., (2010). Children's understanding of teaching: A component of selfregulation? Psychological Test and Assessment Modeling, 52 (4), 454-471.

[29] Rothschild, D., \& Klingenberg, F., (1990). Self and peer evaluation of writing in the interactive ESL classroom: An exploratory study. TESL Canada Journal, 8 (1), 52-65.

[30] Schmeichel, B. J., \& Baumeister, R. F. (2004). Self-regulatory strength. In R. F. Baumeister \& K. D. Vohs (Eds.), Handbook of self-regulation (pp. 84-98). New York: Guilford Press.

[31] Schunk, D. \&Ertmer, P. (2000). Self-regulation and academic learning: Self-efficacy enhancing interventions. In J. Boekarts, P. Pintrich \& M. Zeidner (Eds.) Handbook of Self-Regulation (pp. 13-39). Burlington, MA: Elsevier Academic Press.

[32] Wilde, P. (2010). Self-regulation and the response to concerns about food and beverage marketing to children in the United States. Nutrition Reviews, 67 (3), 155-166.

[33] Zimmerman, B. (2000) Attaining self-regulation: A social cognitive perspective. In M. Boekaerts, P. Pintrich and M. Zeidner (eds) Handbook of Self-Regulation. Burlington, MA: Elsevier Academic Press. 


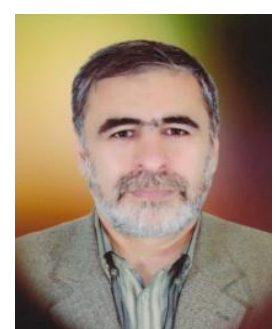

Ebrahim Khodadady was born in Iran in 1958. He obtained his PhD in Applied Linguistics from the University of Western Australia in 1998. He holds TESL Ontario and Canadian Language Benchmarks Placement Test (CLPBPT) certificates and has taught English as a first, second and foreign language to high school and university students in Australia, Canada and Iran.

$\mathrm{He}$ is currently an academic member of English Language and Literature Department at Ferdowsi University of Mashhad, Iran. He was invited as a VIP by Brock University in Canada in 2004 and served as the Associate Director of Assessment Center at George Brown College in Toronto for almost a year. His published books are Multiple-Choice Items in Testing: Practice and Theory (Tehran, Rahnama, 1999), Reading Media Texts: Iran-America Relations (Sanandaj, Kurdistan University, 1999) and English Language Proficiency Course: First Steps (Sanandaj, Kurdistan University, 2001). His main research interests are Testing, Language Learning and Teaching.

Dr. Khodadady is currently a member of Teaching English Language and Literature Society of Iran (TELLSI), TESL Ontario and European Society for Translation Studies. He is on the editorial board of Ferdowsi Review: An Iranian Journal of TESL, Literature and Translation Studies and has reviewed some research papers for Iranian Journal of Applied Linguistics and TESL Canada Journal as a guest reviewer.

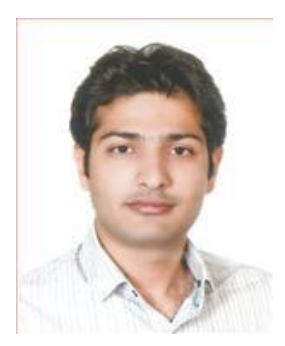

Salim Yassami was born in Tehran in 1983, earned his B.A. in English translation from Islamic Azad University of Tehran in 2006 and was accepted in TEFL at Allameh Tabataba'i University in Tehran, obtained his M.A. in 2010. He is currently a PhD candidate at Ferdowsi University of Mashhad.

$\mathrm{He}$ is at present teaching IELTS preparation courses in different institutes and various courses to B.A. students at Islamic Azad University in Tehran. He is interested in morphology, Discourse Analysis and Second Language Acquisition and its related theories.

Mr. Yassami is a member of Teaching English Language and Literature Society of Iran (TELLSI), one of the prestigious societies in Iran for English students and teachers. 